\title{
Knowledge and Practice Regarding Menstruation among the Visually Challenged Female Students of Westen Nepal
}

\author{
Amrita Paudel ${ }^{1}$, Ram Bilakshan Sah ${ }^{2}$, Anup Ghimire ${ }^{2}$, Avaniendra Chakravartty ${ }^{3}$, Mamta Chhetri ${ }^{1}$, Shankar \\ Bastakoti $^{4}$
}

\author{
${ }^{1}$ School of Public Health and Community Medicine, Chitwan Medical College, Chitwan, Nepal \\ ${ }^{2}$ School of Public Health and Community Medicine, B.P. koirala Institute of Health Sciences, Dharan, Nepal \\ ${ }^{3}$ School of Public Health and Community Medicine, B.P. koirala Institute of Health Sciences, Dharan, Nepal \\ ${ }^{4}$ B.P Koirala Memorial Cancer Hospital, Chitwan, Nepal
}

\section{CORRESPONDENCE}

Amrita Paudel,

School of Public Health and

Community Medicine,

Chitwan Medical College, Chitwan

Email-amreeta.paudel@gmail.com

\section{ARTICLE INFO}

Article History

Submitted: 12 December 2020

Accepted: 3 January, 2021

Published: 8 February,2021

Source of support: None

Conflict of Interest: None

Copyright : (CThe Author(S) 2020 This is an open access article under the Creative Common Attribution license CC-BY 4.0

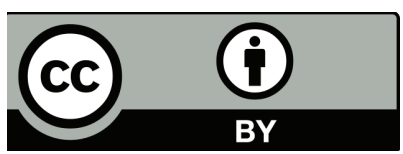

\begin{abstract}
Background: Menstruation is part of the female reproductive cycle starts when girls become sexually mature at the time of puberty.. A visually challenged female faces daily extra challenges for bearing their everyday skills including menstruation hygiene management. Hygienic practices during menstruation are very important as poor menstruation affects the health by increasing vulnerability to infections This study aims to assess the knowledge and practices regarding menstruation among the visually challenged female students.
\end{abstract}

Methods: This cross sectional study was conducted among 121 visually challenged female students of Western Nepal who have attained the menarche. Census method was used. Descriptive and inferential statistics were used to interpret the data.

Results: The mean age was 17.65 years and their age of menarche was 12.7 years. $66 \%$ falls under blindness category and $34.0 \%$ had low vision.52.9\% knew about menstruation before menarche and mother was main source of information. Overall,48.8\% had good knowledge and $52.1 \%$ had satisfactory practice. Knowledge and practice were statistically significant among the visually challenged female students at $p<0.05$.

Conclusion:In Western part of Nepal,Majority follow some forms of restriction poses in family in any forms like restriction to involve in holy activities; avoid sleeping in the bed, performing household activities. Hence, in order to break the silence of taboos,school going visually challenged students should be educated about the facts of menstruation and good hygienic practices.

Keywords: Menstruation, Knowledge. Practice, visually challenged

\section{INTRODUCTION}

Menstruation is part of the female reproductive cycle that starts when girls become sexually mature at the time of puberty. ${ }^{1}$ The profile of the woman's reproductive health is greatly influenced by the girl's reaction to menarche, her beliefs and attitude towards menstruation, and more important her behavior during it. ${ }^{1}$ Most girls are not informed about menarche and how to manage menstrual bleeding, and adolescents also lack knowledge about reproductive health issues. ${ }^{3}$ So, it is difficult for them to adopt with the changes. Further, Blind female adolescent students are obviously disadvantaged as it is hard for them to achieve normal levels of social, emotional and cognitive development. Hygienic practices during menstruation are very important as poor menstruation affects the health by increasing vulnerability to infections of the urinary tract and perineum and the reproductive tract. 4,5,6, Effective menstrual hygiene management (MHM) includes access to clean absorbents, with facilities to change, clean or dispose of these as needed, and access to soap and water for cleaning the body and absorbents. ${ }^{6}$

The knowledge and practice regarding menstruation hygiene done in general adolescent girl in Nepal show the poor menstruation hygiene practice. ${ }^{1} \mathrm{~A}$ lack of 
adequate guidance, facilities, and materials for girls to manage their menstruation in school is a neglected public health, social, and educational issue. ${ }^{7}$ The visually challenged female faces daily extra challenges for bearing their everyday skills including menstruation hygiene management. They need physical and emotional support and assurance that menstruation is normal physiological process. In order to break the silence of a taboo and successfully manage menstrual hygiene, adolescents female need to understand the biologic change they are experiencing and be equipped with the skills to cope with it. It was, therefore, felt as a need to assess the menstruation-related hygienic practices. ${ }^{8}$ Also, there are very few literature available particularly on the issues related to menstruation among visually challenged female. So, thestudy aims to assess the knowledge and practices regarding menstruation among the visually challenged female students of Western Nepal.

\section{METHODS}

A descriptive cross sectional study was done among visually challenged female students of Western Development Region. There were 20 schools for the visually challenged studentsin Western Nepal of which only two schools were for the primary students which was excluded. Census method was used for the data collection and the study duration was December, 2016 to May, 2017.Data was collected by interviewing the visually challenged students by using a pre-tested semi-structured questionnaire. The questionnaire was used to elicit information from each study participant for socio-demographic characteristics, menstrual pattern and knowledge and practices related menstruation hygiene. Content and face validity of the questionnaire was established by literature review and consultation with concerned experts and peer review. Approval for research was obtained from Institutional Review Committee of institute and permission BPKIHS. Individual school was contacted after getting permission from Western Regional Education Directorate. Anonymity and confidentiality was maintained.

Collected data was coded and entered in Microsoft Excel 2007 and analysis was done in Statistical Package for Social Science (SPSS v.11.5). Descriptive statistics and inferential statistics chi-square test was done to see the association of knowledge and practices at $p<0.05$.

\section{RESULTS}

Among 121 respondents ,66.0\% fall under the blindness category and $34.0 \%$ had low vision. The Mean \pm SD age of respondent was $17.65 \pm 3.99$ years. $86 \%$ were Brahmin/
Chhetri. The study population were mainly Hindu (86\%), unmarried(94.2\%), living in nuclear family (62\%) and were studying in lower secondary level. 66.9\% of the family's income status were below poverty line and only $33.1 \%$ had the income status above poverty line. Among 121 respondents $66.0 \%$ fall under the blindness category and $34.0 \%$ had low vision.

The mean age of menarche was $12.7 \pm 1.33$ years. $72 \%$ had menarche on early adolescence and $27.3 \%$ on middle adolescence. It was evident that $52.9 \%$ knew about menstruation before their menarche and Mother (33.8\%) was the prime source of information, followed by sisters, friends, teachers and media.67.8\% had regular cycle of menstruation, $75.2 \%$ has normal duration of blood flow(3 to 5 days). Among 121 students, 3.3\% missed periods few times and $96.7 \%$ recognized periods at mean time till date.Identification of periods is one of the issues for visually challenged.40.5\% identify period by sensation of fluid overflow associated with physical symptoms, $22.3 \%$ by sensation of continuous fluid overflow, about $30.0 \%$ recognize blood during menstruation, $5 \%$ recognize by smell of bleeding during period and others include Calendar method/date wise and mother helps to identify. (Table 1 )

The overall knowledge score was assessed by taking a mean score as a cutoff point and was categorized as poor knowledge and good knowledge. In total of 121 respondents, $48.8 \%$ of the respondents had good knowledge while $51.2 \%$ of the respondents had poor knowledge. There are 16 questions related to assess the practices level of Menstruation hygiene. 52.1\% of the respondent had a satisfactory menstruation hygiene practices while $47.9 \%$ of the respondents had unsatisfactory practices.

Among 121 respondents, $83.5 \%$ of them follow restrictions during menstruation. The commonest restriction was to perform religious activities $(95.0 \%)$ then restriction to enter kitchen (70.3\%), restriction on house hold activities $(49.5 \%)$, restrictions on touching flowers $42.6 \%$ and avoid sleeping in own bed(37.7\%) .During menstruation 51.2\% are treated as untouchables (51.2\%) and $48.8 \%$ are treated normally. For the actions taken by others if mistakenly touched by the respondents, $34.7 \%$ (42) sprinkles holy water, $6.6 \%$ take bath and $6.6 \%$ change sacred thread and rest $52.1 \%$ do nothing.(Table 2 )

There was statistically significant association between knowledge and practice of menstruation among the visually challenged female students at $p$-value $<0.05$. (Table 3) 
Table 1: Knowledge of the respondents regarding menstruation ( $N=121)$

\begin{tabular}{|c|c|c|c|}
\hline Variables & Categories & Frequency(N) & Percent (\%) \\
\hline \multirow[t]{3}{*}{ Menstruation } & Physiological process & 110 & 90.9 \\
\hline & Disease & 7 & 5.8 \\
\hline & Curse & 4 & 3.3 \\
\hline \multirow[t]{3}{*}{ Age of Menarche } & Early adolescence & 53 & 43.8 \\
\hline & Middle Adolescence & 59 & 48.8 \\
\hline & Age of Menarche & 9 & 7.4 \\
\hline \multirow[t]{4}{*}{ Content of Menstruation } & Fresh blood & 74 & 61.2 \\
\hline & Clot & 5 & 4.1 \\
\hline & Content of Menstruation & 39 & 32.2 \\
\hline & Watery Secretion & 3 & 2.5 \\
\hline \multirow[t]{4}{*}{ Source(Organ) of Bleeding } & Uterus & 66 & 54.5 \\
\hline & Vagina & 19 & 15.7 \\
\hline & Source(Organ) of Bleeding & 18 & 14.9 \\
\hline & Ovary & 18 & 14.9 \\
\hline \multirow[t]{2}{*}{ Blood Impure } & Yes & 113 & 93.4 \\
\hline & No & 8 & 6.6 \\
\hline $\begin{array}{l}\text { Absorbent necessary for } \\
\text { Menstrual protection }\end{array}$ & Yes & 121 & 100.0 \\
\hline \multirow[t]{4}{*}{$\begin{array}{l}\text { Appropriate Interval for } \\
\text { changing the absorbent }\end{array}$} & $\begin{array}{l}\text { At least 4-6 hours despite the absorbent } \\
\text { becomes wet }\end{array}$ & 70 & 57.9 \\
\hline & $\begin{array}{l}\text { Absorbent necessary for Menstrual } \\
\text { protection }\end{array}$ & 29 & 24.0 \\
\hline & $\begin{array}{l}\text { Appropriate Interval for changing the } \\
\text { absorbent }\end{array}$ & 10 & 8.3 \\
\hline & Others & 12 & 9.9 \\
\hline \multirow[t]{2}{*}{ Good to share the absorbent } & Yes & 8 & 6.6 \\
\hline & No & 113 & 93.4 \\
\hline \multirow{2}{*}{$\begin{array}{l}\text { Necessary to clean the } \\
\text { external genital }\end{array}$} & Yes & 114 & 94.2 \\
\hline & No & 7 & 5.8 \\
\hline \multirow{2}{*}{$\begin{array}{l}\text { Hygienic to clean genitalia } \\
\text { front to back }\end{array}$} & Yes & 70 & 57.9 \\
\hline & No & 51 & 42.1 \\
\hline \multirow{2}{*}{$\begin{array}{l}\text { Poor menstruation hygiene } \\
\text { predispose to infection }\end{array}$} & Yes & 115 & 95.0 \\
\hline & No & 6 & 5.0 \\
\hline \multirow{2}{*}{$\begin{array}{l}\text { Uncared menstruation pro- } \\
\text { duces a foul odor }\end{array}$} & Yes & 117 & 96.7 \\
\hline & No & 4 & 3.3 \\
\hline \multirow{2}{*}{$\begin{array}{l}\text { Necessities of food and } \\
\text { activity restriction during } \\
\text { menstruation }\end{array}$} & Yes & 33 & 27.3 \\
\hline & No & 88 & 72.7 \\
\hline
\end{tabular}




\section{Table 2: Practices during menstruation}

\begin{tabular}{|c|c|c|c|}
\hline Characteristics & Categories & $\begin{array}{l}\text { Freque- } \\
\text { ncy(N) }\end{array}$ & Percent $(\%)$ \\
\hline \multirow[t]{3}{*}{ Stay during menstruation } & Own house & 118 & 97.5 \\
\hline & Animal Shed & 1 & 0.8 \\
\hline & Neighbor's house & 2 & 1.7 \\
\hline \multirow[t]{3}{*}{ Sleep during menstruation } & Bed & 94 & 77.7 \\
\hline & Floor & 26 & 21.5 \\
\hline & Others & 1 & 0.8 \\
\hline \multirow[t]{3}{*}{ Bathing habits during menstruation } & Daily & 31 & 25.6 \\
\hline & Alternate day & 84 & 69.4 \\
\hline & Every three days gap & 6 & 5.0 \\
\hline \multirow[t]{2}{*}{ Use limited clothes during menstruation. } & Yes & 77 & 64.0 \\
\hline & No & 44 & 36.0 \\
\hline Use of absorbent & Yes & 121 & 100.0 \\
\hline \multirow[t]{3}{*}{ Material used as an absorbent } & Clothes & 31 & 25.6 \\
\hline & Sanitary pad & 28 & 23.1 \\
\hline & Both(clothes and sanitary pad) & 62 & 51.3 \\
\hline \multirow[t]{4}{*}{ Frequency of changing absorbent } & $\begin{array}{l}\text { At least } 4-6 \text { hours despite the absorbent } \\
\text { becomes wet }\end{array}$ & 61 & 50.4 \\
\hline & When the absorbent is completely wet & 30 & 24.8 \\
\hline & Once daily & 11 & 9.1 \\
\hline & Others & 19 & 15.7 \\
\hline \multirow[t]{2}{*}{ Reuse absorbent } & Yes & 80 & 66.1 \\
\hline & No & 41 & 33.9 \\
\hline \multirow[t]{2}{*}{ Ever shared the absorbent } & Yes & 8 & 6.6 \\
\hline & No & 113 & 93.4 \\
\hline \multirow[t]{3}{*}{ Dry absorbents/ undergarments } & Outside in the sunlight & 61 & 50.4 \\
\hline & Outside without sunlight & 43 & 35.5 \\
\hline & Inside bathroom & 17 & 14.0 \\
\hline \multirow[t]{2}{*}{ Process of disposal } & Without wrapping & 20 & 16.5 \\
\hline & Wrapped with paper/plastics & 101 & 83.5 \\
\hline \multirow[t]{5}{*}{ Ways of disposal of absorbent } & Burn it & 50 & 41.3 \\
\hline & Throw it in routine waste & 44 & 36.4 \\
\hline & Throw it in separate dustbin & 9 & 7.4 \\
\hline & Flush it in toilet & 2 & 1.7 \\
\hline & Others & 16 & 13.2 \\
\hline \multirow[t]{2}{*}{ Frequency of cleaning external genitalia } & Every time after Urination & 55 & 45.5 \\
\hline & Every time while changing absorbent & 66 & 54.5 \\
\hline \multirow[t]{3}{*}{ Material use to clean external genitalia } & Soap and water & 90 & 74.4 \\
\hline & Plain water & 30 & 24.8 \\
\hline & Antiseptic solution & 1 & 0.8 \\
\hline \multirow[t]{4}{*}{ Ways of cleaning external genitalia } & Back to front & 7 & 5.8 \\
\hline & Front to back & 56 & 46.3 \\
\hline & Front only & 4 & 3.3 \\
\hline & Random & 54 & 44.6 \\
\hline \multirow{2}{*}{$\begin{array}{l}\text { Wash Hands after changing absorbent and clean- } \\
\text { ing genitalia }\end{array}$} & Yes & 120 & 99.2 \\
\hline & No & 1 & 0.8 \\
\hline
\end{tabular}


Table 3: Association between knowledge and practice of menstruation

\begin{tabular}{|l|l|l|l|l|}
\hline \multirow{2}{*}{$\begin{array}{l}\text { Knowledge } \\
\text { Level }\end{array}$} & \multicolumn{2}{|l|}{ Practice Level } & $\begin{array}{l}\text { Pearson } \\
\text { Chi- } \\
\text { square }\end{array}$ & $\begin{array}{l}\text { p- } \\
\text { value } \\
*\end{array}$ \\
\cline { 2 - 5 } & Unsatisfactory & Satisfactory & 7.026 & 0.008 \\
\hline $\begin{array}{l}\text { Poor } \\
\text { Knowledge }\end{array}$ & $51.2 \%$ & $40.3 \%$ & & \\
\cline { 1 - 3 } $\begin{array}{l}\text { Good } \\
\text { Knowledge }\end{array}$ & $35.6 \%$ & $64.4 \%$ & & \\
\hline *Chi square test used & & & \\
\hline
\end{tabular}

\section{DISCUSSION}

In the present study, out of 121 visually challenged female students, $42.1 \%$ were of 15 to 19 years , $27.3 \%$ were $20-24$ years , $26.4 \%$ were $10-14$ years and rests $4.1 \%$ were above 25 years. The mean age of respondents being $17.65 \pm 3.991$ and range of 11 to 30 years. The study population age group is wider than that in other few studies. ${ }^{19,10}$ whereas many of the study has included adolescents only as a study population. . $11,12,13,3,14,15$ Since this study is unique of its own kind, limited studies have been conducted before. Hence discussion will be based on visually challenged menstruating female wherever available, if not other sighted menstruating female. $71.9 \%$ had menarche on early adolescence and mean age of menarche being 12.7 years. According to the study conducted in various disabilities, age of menarche was earlier in visually impaired than other disabilities. Blind people have menarche earlier than sighted girls suggesting some influence of light. ${ }^{16}$ The age of menarche of girls ranged from 11 to 15 years. ${ }^{3}$ , 14-17 years. ${ }^{17}$ The widely dispersed range of $12-17$ years as age of menarche is found in the study of India. ${ }^{18}$ which is unlike to the present study.

It was observed that $50.0 \%$ of the respondents knew about menstruation before their menarche where similar findings was seen in study conducted in West Bangal, India ${ }^{18}$ The findings is higher in the study done in Raichur, India ${ }^{3}$ where $69.0 \%$ adolescent girls were aware about menstruation before they first experienced it.In a study conducted in Tamil Nadu ${ }^{20}$, West Benga ${ }^{18}$,East Delhi,India ${ }^{19}$ and mothers were the prime source of informant which is alike to the present study findings.

More than sixteen percent (16.3\% )and $22.2 \%$ reported irregular cycle in a study of Raichur(3) and Uttar Pradesh, India. ${ }^{21}$ respectively, whicharelesserthanthisstudy. Normal duration of blood flow was 3 to 5 days which occurred in $75.2 \%$ respondents whereas it was found to be normal as 3-9 days in $80.56 \%$ girls as per Uttar Pradesh, India study. ${ }^{21}$ In this study, since around $50.0 \%$ of them knew about menstruation before menarche, we found that experience during first menstruation where most of the respondents did nothing (43.8\%) followed by Cried (24.8\%) and anxiety (20.6\%). This findings was in contrast to the study of Udupi Taluk. ${ }^{22}$ which revealed that principal emotions associated with menstruation fear $49.0 \%$, followed by a feeling of embarrassment $30.25 \%$, and anxiety in $14.5 \%$. There wasn't any reaction from $22.0 \%$ of the adolescent girls respectively which is alike study conducted abroad. ${ }^{23,24}$ $73.6 \%$ have physical symptoms during menstruation and the most common physical symptoms is abdominal pain $(82.0 \%)$ which is similar to other studies. ${ }^{20,25,26,27,28}$

Assessment of the level of knowledge regarding menstruation among visually challenged female students discloses that $48.8 \%$ had good knowledge and $51.2 \%$ had poor knowledge. The finding is similar in the study done in Rural Nepal. ${ }^{1}$,Nigeria. ${ }^{29}$ and Ethiopia. ${ }^{30}$,Western Ethiopia which were $40.6 \%, 54 \%, 51.3 \%$ and respectively. Contrary to the present study findings high knowledge about menstruation hygiene was obtained in a study done in Amhara, Northern Ethiopia ${ }^{31}$, which is $90.7 \%$ and $91.5 \%$ in Northwest Nigeria ${ }^{32}$, whereas $60.9 \%$ in Western Ethopia. ${ }^{33}$ This difference in knowledge level in Nepal and other countries might be due to the reason that mothers in Nepal were not interested to express their views and to educate their daughters about menstrual hygiene because of the taboo of discussing about menstruation.${ }^{34}$ Also menstruation related hygieneand practicesarenotincluded in the education course of Nepal in School. Similar study done in Shimla,India among adolescents reported lower knowledge than that of the present study $(29.0 \%) .^{35}$

In the present study, $52.1 \%$ have a satisfactory practice. The findings of this study was lower than the study conducted in Ethiopia. ${ }^{31}$ and North Western Nigeria. ${ }^{32,32}$ which were $90.9 \%$ and $88.7 \%$.Comparatively, lower level of practice was recorded for the similar study conducted on Gujjar girls. ${ }^{36}$ and Ethiopia among high school girls. ${ }^{33}$ ,Rural Nepal. ${ }^{1}$ with $3.1 \%, 39.9 \%$ and $12.9 \%$ respectively. The lower practice of Nepalese girls than other countries could be related to poor knowledge of Nepal's girls about menstrual hygiene which affects their level of practice. Similarly, Different restrictions were practiced by most of the girls in the present study, possibly due to the different rituals in their communities; the same were practiced by their mothers or other elderly female in the family.

In the present study Significant associations were found between the level of knowledge and practice with $p<0.05$. This findings is similar to the another study of Nepal. ${ }^{35}$ and Ghana. ${ }^{24}$, and Northwestern Nigeria. ${ }^{32}$ The finding is contrary from the study done in Bangalore, India.$^{37}$ which showed that there was no association between knowledge and practice This difference could be due 
to the cultural restriction and taboos in the Bangalore which affects their level of menstrual hygiene practices regardless of the level of knowledge.

\section{CONCLUSION}

Almost half respondent (48.8\%) had a good knowledge and $52.1 \%$ had a satisfactory practice regarding menstruation. Knowledge and practices is significantly associated in the study. Knowledge is a power tool and will influence good practices among females. So, emphasis should be given on educating females and making them aware about issues related to menstruation. School based intervention on comprehensive sexual education is strongly recommended for the betterment of practices and use of menstruation anatomy kit for teaching visually challenged students.

\section{REFERENCES}

1. Adhikari P. Knowledge and practice regarding menstrual hygiene in rural adolescent girls of Nepal. Kathmandu Univ Med J [Internet]. 2007;5(3):382-6. Available from: https:// www.ncbi.nlm.nih.gov/pubmed/18604059

2. Fetohy EM. Impact of a health education program for secondary school Saudi girls about menstruation at Riyadh city. J Egypt Public Health Assoc. 2007;82(1-2):105-26.

3. Ade A, Patil R. Menstrual Hygiene and Practices of Rural Adolescent Girls of Raichur . Int J Biol Med Res. 2013;3(1):3014-7.

4. Abd-El Sattar Ali R. Effect of Health Educational Program for Females Blinded Adolescents Students Regarding Reproductive Health. Am J Nurs Sci [Internet]. 2015;4(1):1. Available from: http://www.sciencepublishinggroup.com/ journal/paperinfo.aspx?journalid=152\&doi=10.11648/j. ajns.20150401.11

5. Haque SE, Rahman M, Itsuko K, Mutahara M, Sakisaka $K$. The effect of a school-based educational intervention on menstrual health: an intervention study among adolescent girls in Bangladesh. BMJ Open [Internet]. 2014;1-9. Available from: http://bmjopen.bmj.com/ content/bmjopen/4/7/e004607.full.pdf

6. Hennegan J, Montgomery P. Interventions Improve Education and Psychosocial Outcomes for Women and Girls in Low and Middle Income Countries ? A Systematic Review. PLoS One [Internet]. 2016;49:1-21. Available from: Do Menstrual Hygiene Management Interventions Improve Education and Psychosocial Outcomes for Women and Girls in Low and Middle Income Countries? A Systematic Review
7. Sommer M, Caruso BA, Sahin M, Calderon T, Cavill S. A Time for Global Action : Addressing Girls' Menstrual Hygiene Management Needs in Schools. PLoS One. 2016;1-9.

8. Nayak S, Toppo NA, Tomar SP, Kasar PK, Tiwari R. A study on practices regarding menstrual hygiene among adolescent girls of urban areas of Jabalpur District. Int J Med Sci Public Heal. 2016;5(11):2355-7.

9. Thakre SB, Thakre SS, Reddy M, Rathi N, Pathak K, Ughade S. Menstrual hygiene: Knowledge and practice among adolescent school girls of Saoner, Nagpur District. J Clin Diagnostic Res. 2011;5(5):1027-33.

10. Kumar D, Goel NK, Puri S, Pathak R, Singh Sarpal S, Gupta $S$, et al. Menstrual pattern among unmarried women from Northern India. J Clin Diagnostic Res. 2013;7(9):1926-9.

11. Akpenpuun, Rumun J, Msuega AP. MENSTRUAL KNOWLEDGE AND PRACTICES AMONG ADOLESCENT FEMALES IN MAKURDI METROPOLIS. Glob J Interdiscip Soc Sci. 2014;3(3):113-21.

12. Santina T, Wehbe N, Ziade FM, Nehme M. Assessment of Beliefs and Practices Relating to Menstrual Hygiene of Adolescent Girls in Lebanon. Int J Heal Sci Res. 2013;3(12):75-88.

13. Amirtha G, KCP, Sarkar S, Lakshminarayanan S. MENSTRUAL HEALTH - KNOWLEDGE, PRACTICES AND NEEDS OF ADOLESCENT SCHOOL GIRLS IN PONDICHERRY. Indian J Matern Child [Internet]. 2013;15(1):1-5. Available from: http://www.popline.org/node/572119

14. Anusree PC, Roy A, Sara AB, Vcm F, Babu GP, Tamrakar A. Knowledge Regarding Menstrual Hygiene among Adolescent Girls in selected school, Mangalore with a View to Develop an Information Booklet. IOSR J Nurs Heal Sci [Internet]. 2014;3(1):55-60. Available from: http:// iosrjournals.org/iosr-jnhs/papers/vol3-issue1/Version-4/ J03145560.pdf

15. Kanchan C, Vsv P. Menstrual Hygiene: Knowledge and Practice among Adolescent School Girls. Panacea J Med Sci. 2016;6(1):31-3.

16. JoshiGA, JoshiPG. Study of menstrual patterns in adolescent girls with disabilities in a residential institution. Int J Adolesc Med Heal [Internet]. 2015;27(1):65-8. Available from: https://www.ncbi.nlm.nih.gov/pubmed/24887953

17. Sudeshna R, Aparajita D. DETERMINANTS OF MENSTRUAL HYGIENE AMONG ADOLESCENT GIRLS : A MULTIVARIATE ANALYSIS. Natl J Community Med. 2012;3(2):294-301. 
18. Deo DS, Ghattargi CH. Perceptions and Practices Regarding Menstruation: A Comparative Study in Urban and Rural Adolescent Girls . Indian J Community Heal [Internet]. 2005;30(1). Available from: http://medind.nic.in/iaj/t05/ i1/iajt05i1p33.pdf

19. Nair P, Grover VL, Kannan A. Awareness and practices of menstruation and pubertal changes amongst unmarried female adolescents in a rural area of East Delhi Nair $P$, Grover VL, Kannan A T - Indian J Community Med. Indian J Community Heal. 2007;32(2).

20. Ravisankar AK, Kanmani K. Problems Related to Menstruation amongst Women with Visual Disability in Tamil Nadu. Int J Humanit Soc Stud. 2014;2(9):74-8.

21. Shukla MK, Priya N, Srivastava A. A cross sectional study of knowledge and practices regarding menstrual hygiene, in undergraduate student girls of Moradabad, Uttar Pradesh, India. Int J Community Med Public Heal. 2016;3(7):175964.

22. Kamath R, Ghosh D, Lena A, Chandrasekaran V. A study on knowledge and practices regarding menstrual hygiene among rural and urban adolescent girls in Udupi Taluk , Manipal, India. Glob J Med Public Heal [Internet]. 2013;2(4):1-9. Available from: http://www.gjmedph.com/ uploads/O2-Vo2No4.pdf

23. Ramachandra K, Gilyaru S, Eregowda A, Yathiraja S, Ramachandra K, Pediatr JC. A study on knowledge and practices regarding menstrual hygiene among urban adolescent girls. Int J Contemp Pediatr. 2016;3(1):142-5.

24. Ameade EPK, Garti HA. Relationship between Female University Students' Knowledge on Menstruation and Their Menstrual Hygiene Practices: A Study in Tamale, Ghana. Adv Prev Med. 2016;(September).

25. Geethu C, Paul EP, Thomas JE, Pullan CS, Hemalatha S, Sivakumar T. Appraisal of menstrual hygiene management among women in a rural setting : a prospective study. Int J Community Med Public Heal [Internet]. 2016;3(8):2191-6. Available from: http://menstrualhygieneday.org/wpcontent/uploads/2017/03/Appraisal.pdf

26. Ekong I, Udofia E, Johnson O, Ekanem US. Menstrual problems and their prevalence among adolescents in Akwa Ibom. Int J Curr Res Acad Rev [Internet]. 2015;3(8):96105. Available from: https://www.researchgate.net/ publication/283855494_Menstrual_problems_and_ their_prevalence_among_adolescents_in_Akwa_Ibom

27. Adinma ED, J.I.B.Adinma. Perceptions and Practices on Menstruation Amongst Nigerian Secondary School Girls. Afr J Reprod Health. 2008;12(1).

28. Chan SSC, Yiu KW, Yuen PM, Sahota DS, Chung TKH. Menstrual Problems and health -seeking behavior in Hong
Kong Chinese girls Menstrual problems and healthseeking behaviour in Hong Kong Chinese girls. 18 Hong Kong Med J Vol. 2009;15(October 2016):18-23.

29. Olabanjo OO, Olorunfemi AO, Phillips A, Ogunsola O. Knowledge, Practices And Socio-Cultural Restrictions Among In-School Adolescents In Ile-Ife, Nigeria. Internet J Prev Med. 2014;16(1):1-6.

30. Tegegne TK, Sisay MM. Menstrual hygiene management and school absenteeism among female adolescent students in Northeast Ethiopia. BMC Public Health [Internet]. 2014;14:1118. Available from: http://www. pubmedcentral.nih.gov/articlerender.fcgi?artid $=4232635$ \&tool=pmcentrez\&rendertype=abstract

31. Gultie TK. Practice of menstrual hygiene and associated factors among female Mehalmeda high school students in Amhara regional state, Ethiopia. 2014;2(3):189-95.

32. Lawan UM, Yusuf NW, Musa AB. Menstruation and menstrual hygiene amongst adolescent school girls in Kano, Northwestern Nigeria. Afr J Reprod Health. 2010;14(3):201-7.

33. Upashe SP, Tekelab T, Mekonnen J. Assessment of knowledge and practice of menstrual hygiene among high school girls in Western Ethiopia. BMC Womens Health [Internet]. 2015;15(1):84. Available from: http:// www.ncbi.nlm.nih.gov/pubmed/26466992\%5Cnhttp:// www.pubmedcentral.nih.gov/articlerender. fcgi?artid=PMC4606849

34. Gultie T, Hailu D, Workineh Y, Auemaneekul N, Bhandari $\mathrm{S}$, Kerdmongkol $\mathrm{P}$, et al. Relationship between Female University Students' Knowledge on Menstruation and Their Menstrual Hygiene Practices: A Study in Tamale, Ghana. BMJ Open [Internet]. 2014;4(1):1-9. Available from: http:// www.sciencepublishinggroup.com/journal/paperinfo.asp $x$ ?journalid=152\&doi=10.11648/j.ajns.20150401.11

35. Mahajan A, Kaushal K. Original Article A descriptive study to assess the knowledge and practice regarding menstrual hygiene among adolescent girls of Government School of Shimla , Himachal Pradesh. 2017;99-103.

36. Abioye-Kuteyi EA. Menstrual Knowledge and Practices Amongst Secondary School Girls in Ile Ife, Nigeria. [Internet]. Vol. 120, The journal of the Royal Society for the Promotion of Health. 2000. p. 23-6. Available from: http://www.ncbi.nlm.nih.gov/pubmed/10918779

37. Bobhate PS, Shrivastava SR. A cross sectional study of knowledge and practices about reproductive health among female adolescents in an urban slum of Mumbai [Internet]. Vol. 5, Journal of Family and Reproductive Health. 2011. p. 119-26. Available from: http://ovidsp. ovid.com/ovidweb.cgi?T=JS\&CSC=Y\&NEWS=N\&PAGE=full text $\& D=$ cagh $\& A N=20123086007$ 